九州大学学術情報リポジトリ

Kyushu University Institutional Repository

\title{
When does the group effect on oxygen consumption appear in fish?
}

\section{Kanda, Takeshi}

Department of Fisheries, Faculty of Agriculture, Kyushu University

Itazawa, Yasuo

Department of Fisheries, Faculty of Agriculture, Kyushu University

https://doi.org/10.5109/23824

出版情報: 九州大学大学院農学研究院紀要. 30 (4)，pp. 197-207，1986-09. Kyushu University バージョン：

権利関係 : 
J. Fac. Agr., Kyushu Univ., 30 (4), 197-207 (1986)

\title{
When does the group effect on oxygen consumption appear in fish?*
}

\author{
Takeshi Kanda $†$ and Yasuo Itazawa \\ Department of Fisheries, Faculty of Agriculture, Kyushu University 46-04, \\ Hakozaki, Fukuoka 812 \\ (Received December 7, 1985)
}

\begin{abstract}
Grouping effects on metabolic rate of grouped fish in comparison with isolated individuals appeared during the postlarval stage, 6 or 7 days post hatch in carp and 5 days in medaka, and became clear at the early juvenile stage, at 9 to 15 days post hatch in the former and up to 11 days in the latter. These stages coincide with the age when the fishes began to grow rapidly.
\end{abstract}

\section{INTRODUCTION}

Metabolic rate in fish, expressed as the rate of oxygen consumption per unit weight, has been reported to be lower in groups than in isolated individuals in many species : goldfish Carassius auratus (Shlaifer, 1938), perch Perca fluviatilis (Geyer and Mann, 1939), brook trout Salvelinus fontinalis (Job, 1955), stickleback Gasterosteus aculeatus and dace Phoxinus laevis (Stefan, 1958), blacktail shiner Notropis venustus and red shiner N. lutrensis (Delco and Beyers, 1963), bream Abramis brama (Ryzhkov, 1970), gizzard shad Dorosoma cepedianum, golden shiner Notemigonus crysoleucas, black bullhead Ictalurus melas, logperch Percina caprodes, bullheaded minnow Pimephales vigilax, red shiner, bluegill Lepomis macrochirus, silvery minnow Hybognathus nuchalis, Gulf killifish Fundulus similis, common killifish F. grandis, broad killifish Cyprinodon uariegatus, mosquitofish Gambusia affinis and striped mullet Mugil cephalus (Parker, 1973), rainbow trout Salmo gairdneri and medaka Oryzias latipes (Itazawa et al., 1978), swordfish Xiphophorus helleri (Smatresk and Herreid, 1980), and catfish eel Plotosus anguillaris (Kanda and Itazawa, 1981). This reduction in oxygen consumption of fish in a group is called the "group effect" on oxygen consumption.

Ryzhkov (1968) using Sevan trout subspecies Salmo ischchan aestivalis and S. i. gegarkuni, and Malyukina and Konchin (1969) using Sevan trout and Baltic salmon Salmosalar, concluded that the group effect may appear as early as the embryo. But Konchin (1971) demonstrated that no reduction in oxygen consumption was observed in eggs, larvae or juveniles of Salmo ischchan aestivalis. The stage when the group effect on metabolic rate first appears is,

* Group Effects on Physiological and Ecological Phenomena in Fish-IV

$\dagger$ Present address : The Fisheries Laboratory, Faculty of Agriculture, Miyazaki University, Akamizu, Nobeoka, Miyazaki 889-05 
therefore, uncertain. This study presents the results of our attempts to identify the stages when the group effect on oxygen consumption appears in larvae and juveniles of carp and medaka.

\section{MATERIALS AND METHODS}

Carp. -Fertilized eggs of carp Cyprinus carpio obtained from a single female fish reared with three males were hatched in a glass tank $(30 \times 60 \times 36 \mathrm{~cm})$ set in a constant temperature room. The eggs hatched 4 to 5 days after fertilization. The larvae were fed on live water fleas (Daphnia pulex), always leaving an excess of living water fleas in the tank.

Rates of oxygen consumption of the larvae and juveniles were determined by a closed method at $1,2,3,4,5,6,7,9$ and 15 days post hatching. There were $1,3,5$ or 10 , and 15 fishes in glass bottles of $20,50,100$ and $280 \mathrm{~cm}^{3}$, respectively, for 10 hours or more. The volume per fish was 17 to $20 \mathrm{~cm}^{3}$, except in the 10 fish group where the volume per individual was $10 \mathrm{~cm}^{3}$. A total of fourty-seven bottles (10 bottles contained an isolated fish each, 10 bottles contained 3 fishes, 5 bottles contained 5 fishes, 5 bottles contained 10 fishes and 5 bottles contained 15 fishes, and there were 3 control bottles of each size) were immersed in water in a constant temperature tank $(70 \times 90 \times 20$ $\mathrm{cm})$. So that it was not possible for fish to see fish in other bottles, the bottles were separated by opaque plastic plates. Water temperature was kept homogeneous and constant at $20.4 \pm 0.2^{\circ} \mathrm{C}(\overline{\mathrm{X}} \pm \mathrm{SD})$. Oxygen consumption of fish was calculated from the difference between oxygen concentration in the bottle containing fish and that in the control bottle which contained no fish. The magnitude of reduction in oxygen consumption by the group effect (GE) was expressed as an index, GE $=100\left(\dot{\mathrm{V}}_{0_{2}}\right.$ in isolated fish $-\dot{\mathrm{V}}_{0_{2}}$ in grouped fish $) /$ $\dot{\mathrm{V}}_{0_{2}}$ in isolated fish, where $\dot{\mathrm{V}}_{\mathrm{O}_{2}}$ is the rate of oxygen consumption per unit weight. Total length, wet weight and dry weight of 20 to 50 fishes of each stage were measured. Morphological features of the fish of each stage were also observed.

Medaka. -Fertilized eggs of medaka, or Japanese killifish, Oryzias Iatipes, were obtained from mass culture of about 500 fish and raised in a plastic tank $(30 \times 45 \times 27 \mathrm{~cm})$ in a constant temperature room. The eggs hatched 7 to 9 days after fertilization, and only the larvae hatched on the 8th day after fertilization were used as the experimental stock. They were fed on live rotifers (Brachionus calyciflorus) beginning at one day post hatch, always leaving an excess of living rotifers in the tank. Assorted feeds made from fish meal, small aquatic invertebrates and vegetables, milk, yeast, vitamins and minerals were also used after 6 days post hatch.

Rates of oxygen consumption of the larvae and juveniles 1, 3, 5, 7 and 11 days after hatching were determined by almost the same method as that used for carp, keeping 1, 3, 5 and 14 fishes in glass bottles of 20, 50, 100 and 280 $\mathrm{cm}^{3}$, respectively, for more than 10 hours. The volume per individual fish was $20 \mathrm{~cm}^{3}$, except in the case of groups of 3 fishes in which the volume per fish was $17 \mathrm{~cm}^{3}$. Water temperature was $24.5 \pm 0.2^{\circ} \mathrm{C}$ during growing out and $24.5 \pm$ 
$0.1{ }^{\circ} \mathrm{C}$ during experimentation. The index of group effect, GE, was calculated. Morphometry, and morphological observations were carried out at each stage.

\section{RESULTS}

Carp. - The rate of oxygen consumption per unit fish weight was not different between isolated individuals and grouped fish, and also not different among fish in groups of different sizes, when they were less than 6 days post hatch.

An apparent reduction in oxygen consumption of grouped fish appeared in 6 day old fish in groups of 10 fishes, although the reduction was not statistically significant $(\mathrm{P}>0.05)$. Statistically significant reduction of the GE $(\mathrm{P}<0.05)$ was first recognized in fish of 9 days old in groups of 3,10 and 15 fishes. Highly significant reductions $(\mathrm{P}<0.01)$ were observed in fish of 15 days in groups of 3, 5, 10 and 15 fishes (Fig. 1). The index of GE remained under 10\% until after 5 days, and was over $20 \%$ in fish of 7 days (Fig. 2).

Total length, wet weight and dry weight of the fish showed a rapid increase
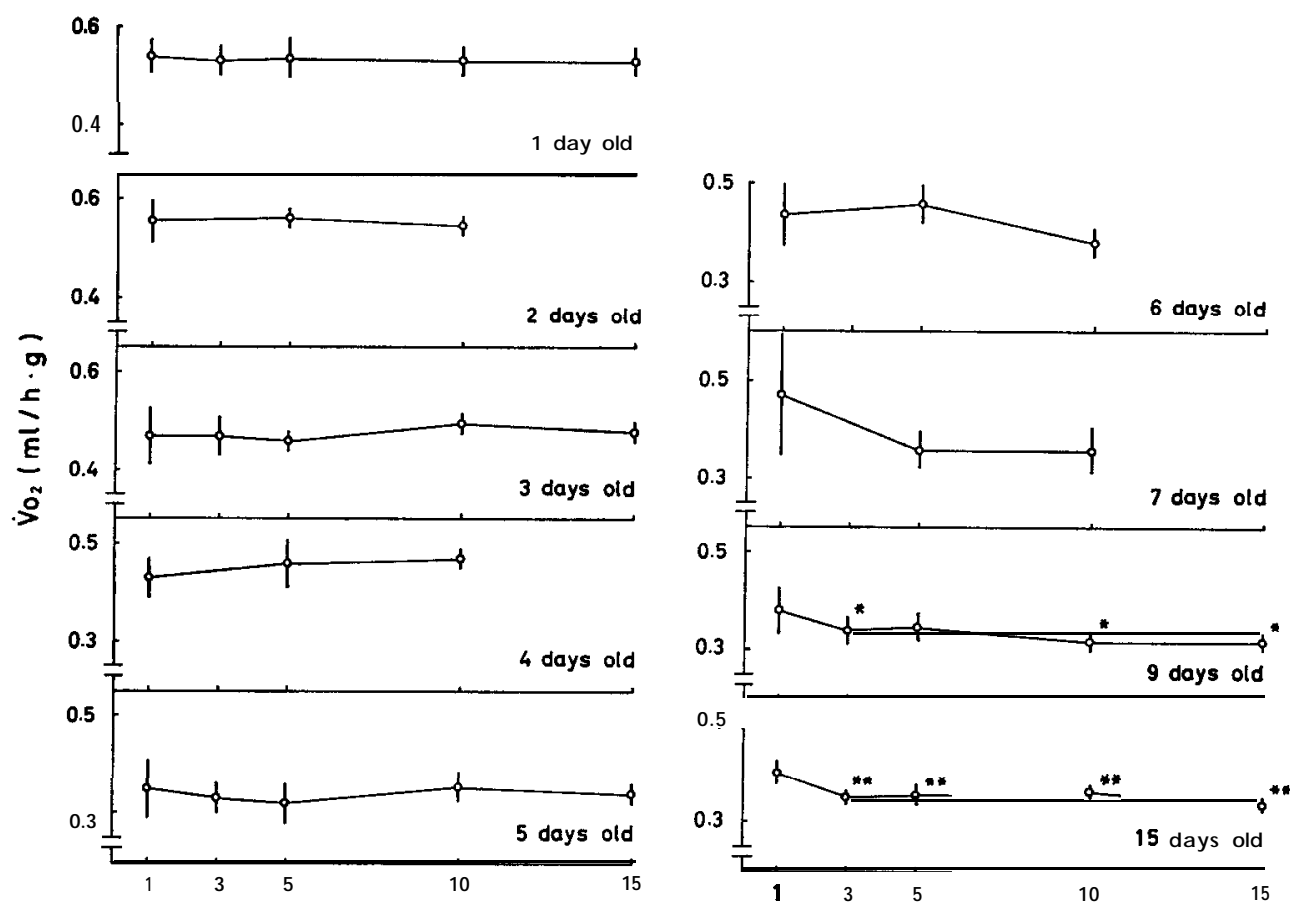

Number of fish

Fig. 1. Oxygen consumption of carp in isolation and in groups of various number of fish at various ages. Oxygen consumption per unit weight is shown by the mean value (circles) and the standard deviations (vertical bars). Statistically significant reduction $(\mathrm{p}<0.05)$ in oxygen consumption compared with isolated fish is shown by an asterisk and highly significant reduction $(\mathrm{p}<0.01)$ by double asterisks. 


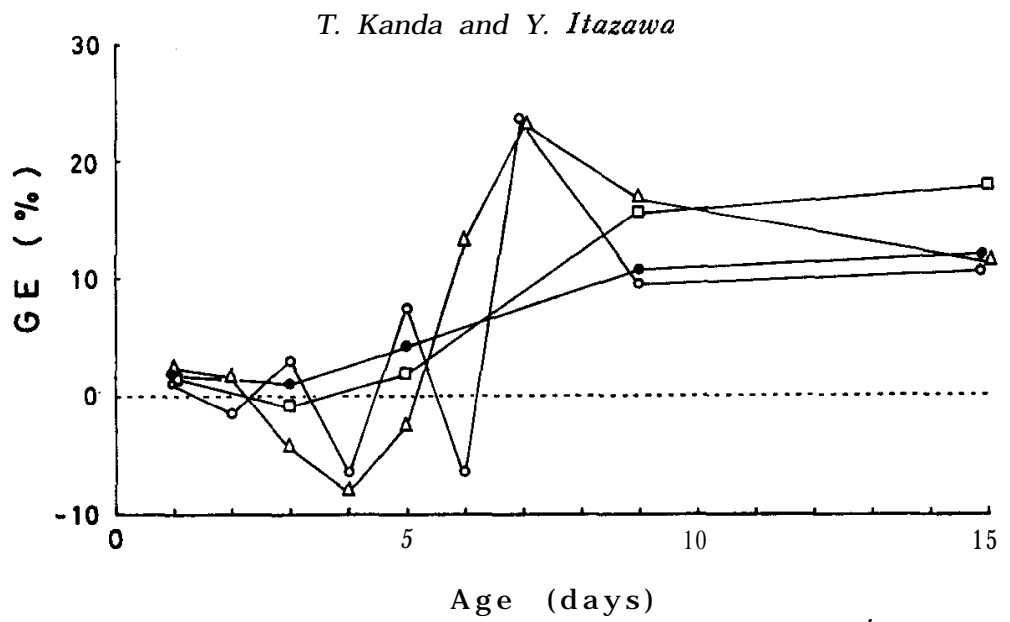

Fig. 2. Index of group effect on oxygen consumption, $\mathrm{GE}=100\left(\dot{\mathrm{V}}_{0_{2}}\right.$ in isolated fish- $\mathrm{V}_{\mathrm{O}_{2}}$ in grouped fish)/ $\dot{\mathrm{V}}_{\mathrm{O}_{2}}$ in isolated fish, of carp in groups of various number of fish at various ages. Solid circles are the values in groups of 3 fishes, open circles those in groups of 5 fishes, triangles those in groups of 10 fishes and squares those in groups of 15 fishes.

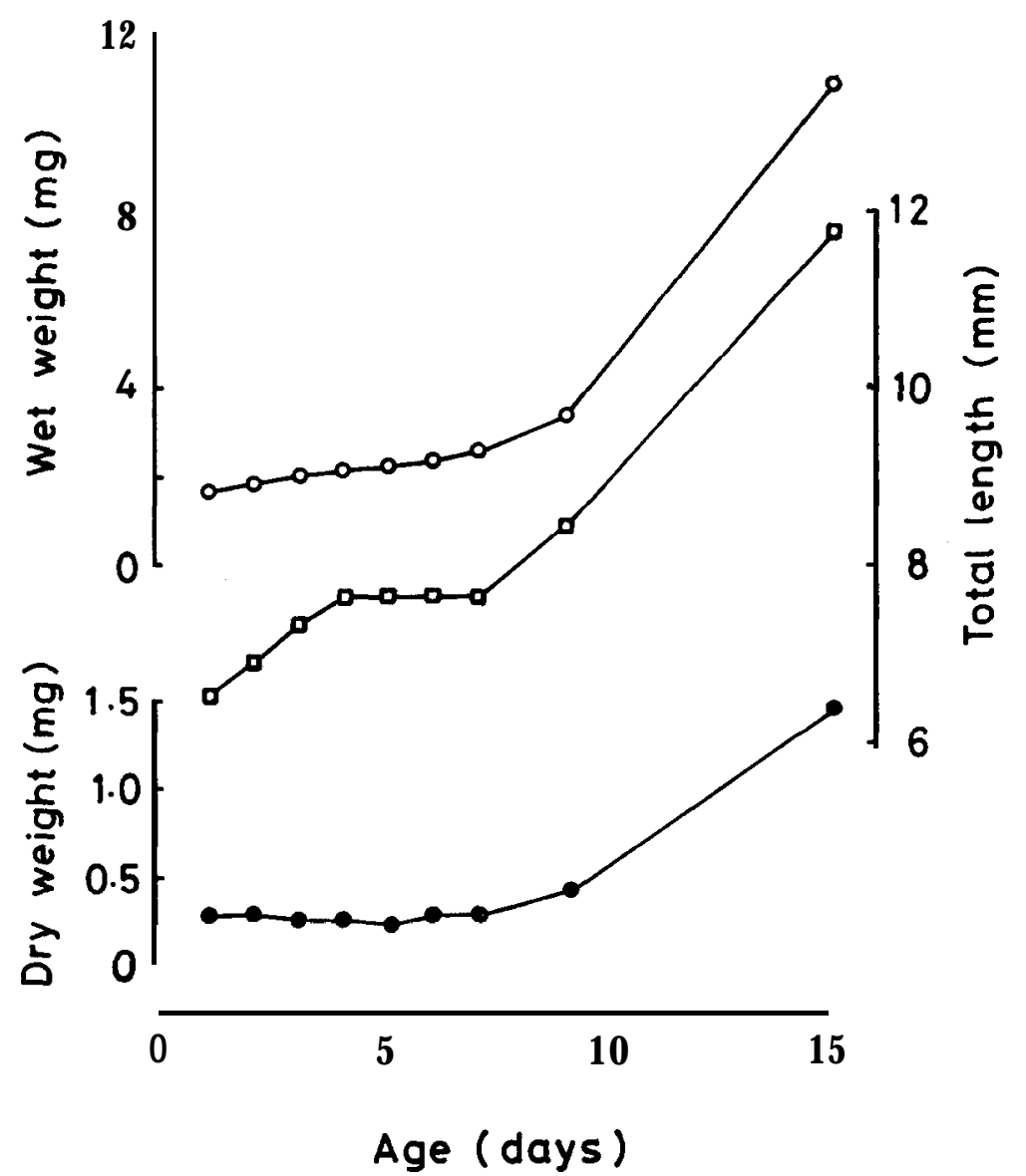

Fig. 3. Growth in wet weight, dry weight and total length of carp. Open circles show wet weight, squares total length and solid circles dry weight. 


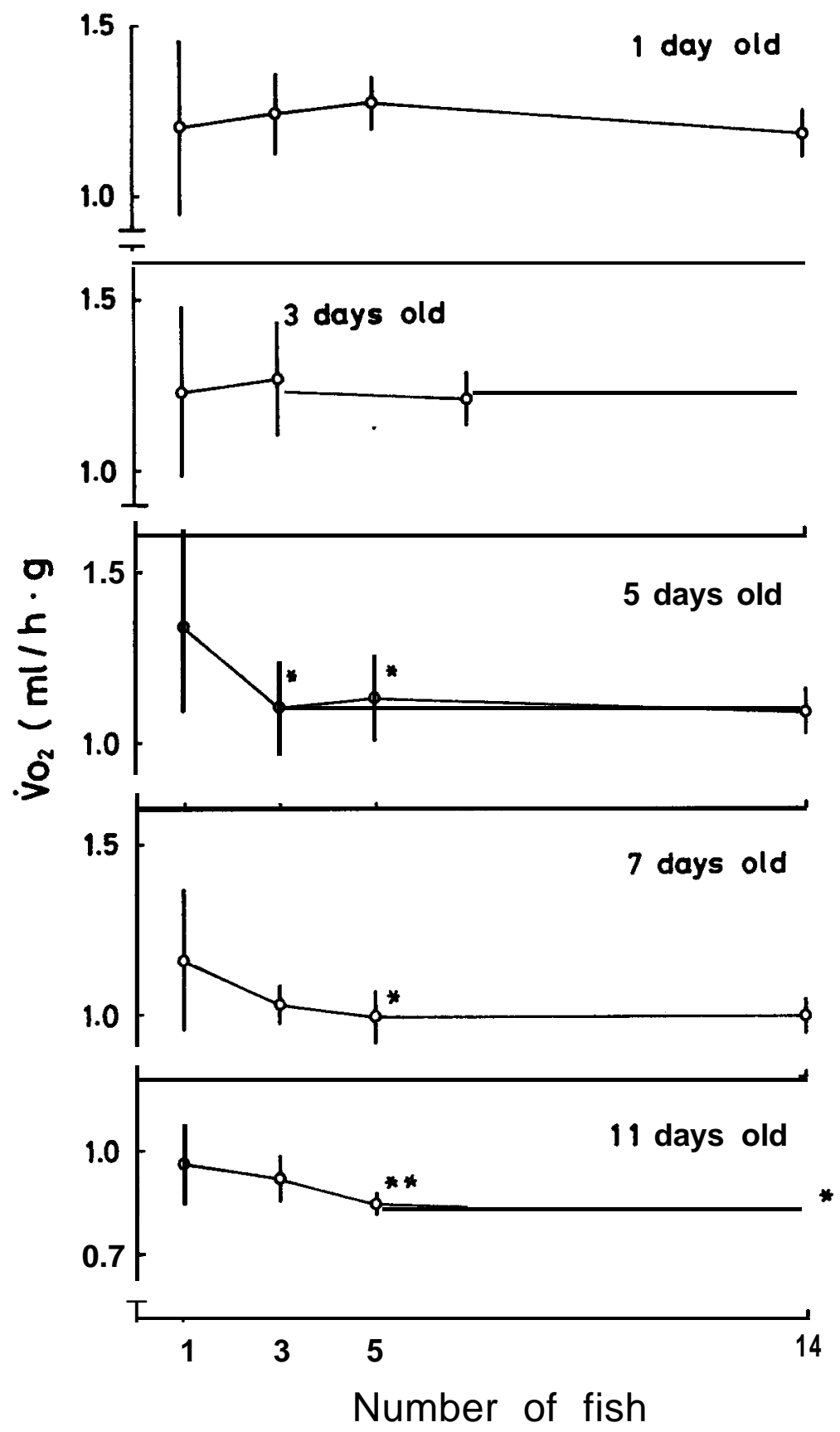

Fig. 4. Oxygen consumption of medaka in isolation and in groups of various number of fish at various ages. Symbols are the same as those for Fig. 1. 
after 7 days (Fig. 3). Fish of 2 days had a yolk sac of $2.75 \pm 0.12 \mathrm{~mm}$ along the body axis and $0.39 \pm 0.07 \mathrm{~mm}$ in the dorsoventral direction, and no gas in their gas bladder. At this age, periods of active swimming were of only very short duration, with the greatest amount of time spent lying on the bottom.

Three day old fish with a yolk sac $(2.71 \pm 0.19 \mathrm{~mm} \times 0.23 \pm 0.04 \mathrm{~mm})$ had gas in their gas bladder of $0.76 \pm 0.09 \mathrm{~mm}$ long and $0.36 \pm 0.03 \mathrm{~mm}$ high, and were able to perform sustained swimming. In 4 day old fish, the yolk sac size was reduced to vestigial, and the digestive tract of 11 out of 15 fishes was found to contain food. In 5 day old fish, the yolk sac had disappeared, and the digestive tract of all fishes contained food. Swimming movement became active and the digestive tract was full of food in 6 and 7 day old fish. In some 7 day old fish and all 8 day old fish, caudal fin rays were apparent. The gas bladder grew steadily, and showed double cavity structure in 7 out of 15 fishes of 15 days old. In fish of 15 days old, the caudal fin showed almost the same features as adult fish, and rays of the dorsal and anal fins appeared.

Medaka. - The rate of oxygen consumption per unit fish weight was not different between isolated individuals and grouped fish, and also not different among fish in groups of different sizes, until after fish were 3 days old. Reduction in oxygen consumption of grouped fish appeared in 5 day old fish in groups of 3 and 5 fishes, and these reductions were statistically significant $(\mathrm{P}<0.05)$. Eleven day old fish showed highly significant reductions $(\mathrm{P}<0.01)$ in 5 fish groups and significant reductions in 14 fish groups (Fig. 4). Index of group effect, GE, remained within $\pm 6 \%$ until after 3 days old, and reached

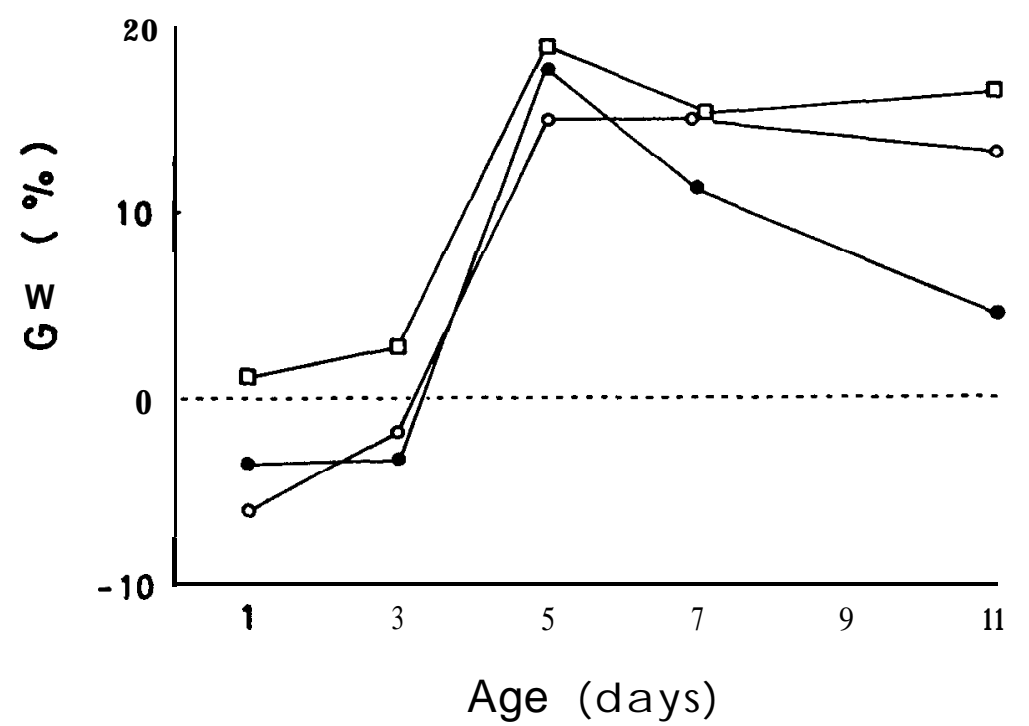

Fig. 5. Index of group effect on oxygen consumption, GE, of medaka in groups of various number of fish at various ages. Solid circles are the values in groups of 3 fishes, open circles those in groups of 5 fishes and squares those in groups of 14 fishes. 
over $13 \%$ in 5 day old fish (Fig. 5).

Total length, wet weight and dry weight of the fish showed a rapid increase after 3 days (Fig. 6). Newly hatched larvae had a yolk sac $(0.85 \pm 0.09 \mathrm{mmx}$ $0.81 \pm 0.09 \mathrm{~mm}$ ) that contained an oil globule, no gas in their gas bladder, and were always lying on the bottom. In fish of 1 day old having a yolk sac $(0.78$ $\pm 0.06 \mathrm{~mm} \times 0.64 \pm 0.06 \mathrm{~mm}), 8$ out of 12 fishes observed had gas in their gas bladder and had the ability to swim near the surface. In 2 day old fish, both yolk sac and oil globule sizes were reduced to vestigial. All of the fish contained gas in their gas bladder and swam actively. In 3 day old fish, both the yolk sac and oil globule disappeared, food was observed in the digestive tract, and the rays of the caudal fin appeared. In 5 day old fish, the digestive tract was
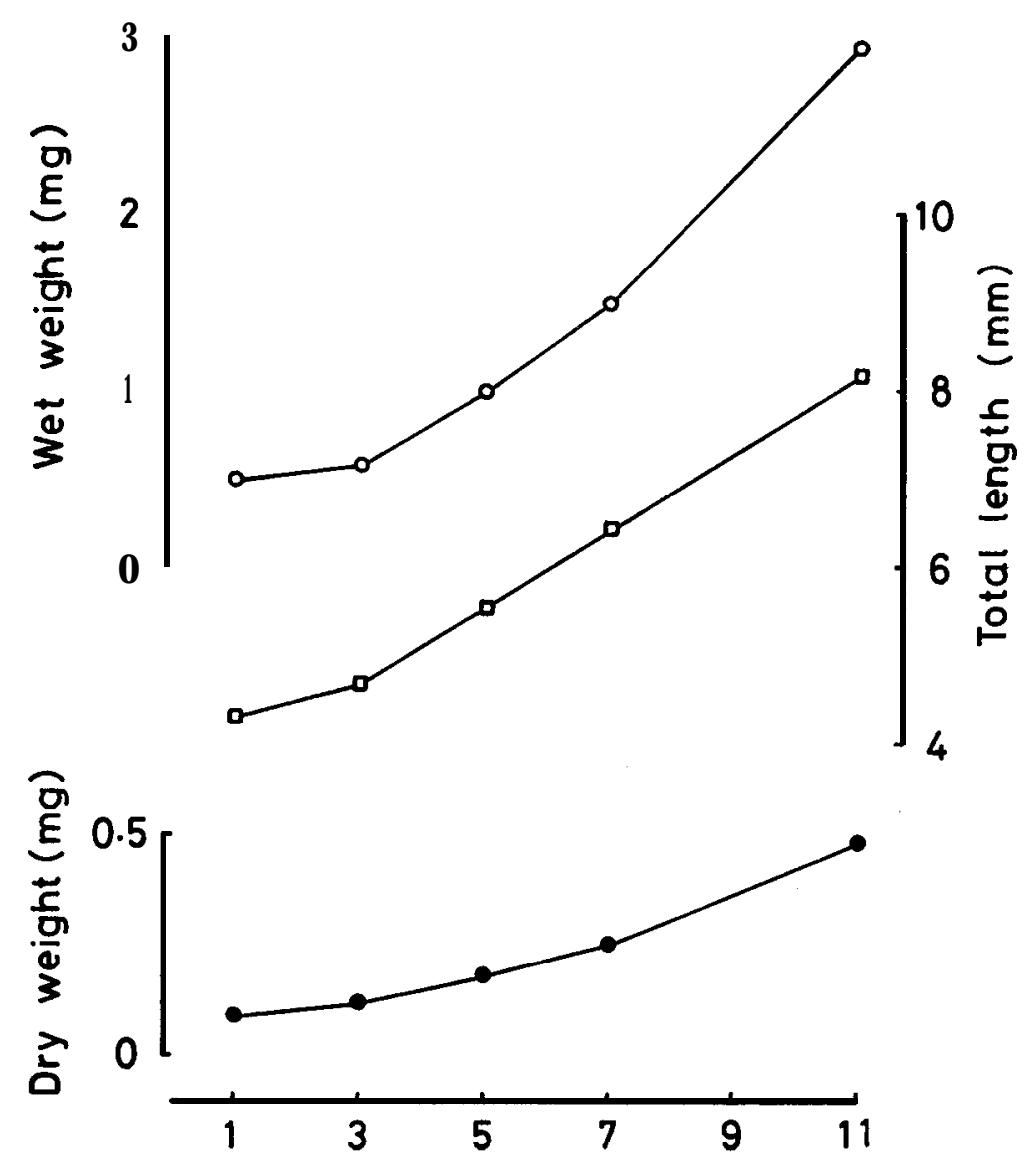

Age (days)

Fig. 6. Growth in wet weight, dry weight and total length of medaka. Symbols are the same as those for Fig. 3. 
full of food, and the rays of the dorsal and anal fins appeared. In 7 day old fish, the caudal fin showed features almost the same as those in adult fish.

\section{DISCUSSION}

The group effect on oxygen consumption in carp appeared at 6 or 7 days and became clear with growth at 9 to 15 days (Figs. 1 and 2). In medaka it appeared at 5 days and became clear with growth up to 11 days (Figs. 4 and 5). Based on morphological observations, the group effect may be said to first appear in the postlarval stage and become clear in the early juvenile stage. The postlarval stage is defined as the stage where feeding begins, following absorption of yolk, and ending at attainment of the proper number of fin rays in all fins. This is the stage with the greatest changes in morphology and ecology, e. g. from planktonic life to active swimming in scombrids, from leptocephalus to elver in anguilliformes, and from planktonic life to benthic life with translocation of an eye in pleuronectiformes. The juvenile stage is defined as the stage between postlarva and adult when features and proportions of body regions are changing towards those of adult fish (Watanabe and Hattori, 1971). The postlarval and juvenile stages of carp and medaka coincide with the stages when the fishes begin to increase rapidly in length and weight (Figs. 3 and 6) and begin to actively swim and feed.

The difference in the age of carp and medaka when the group effect appears is considered to be related to the difference in durations of the embryonic periods. Medaka hatch out in a more advanced state at 7 to 9 days after fertilization at $25^{\circ} \mathrm{C}$ than carp that hatch out 4 or 5 days after fertilization at $20^{\circ} \mathrm{C}$.

Konchin (1971) attributed the reduction in oxygen consumption of grouped individuals of Sevan trout to local lack of oxygen in water surrounding grouped fish. In the present experiments, however, the reduction in oxygen consumption of grouped fish is not considered to be the result of local shortage of oxygen because the reduction first appeared when fish began to actively swim and stir the water, and because oxygen level of water was kept above $100 \mathrm{mmHg}$ during the experimentation.

The group effect on oxygen consumption or reduction in oxygen consumption of grouped fish is generally considered to be due in part to an increased oxygen consumption of isolated fish due to increases in locomotive activity and metabolic activity, and in part to decreased oxygen consumption of grouped fish due to decreases in locomotive activity and metabolic activity. The higher locomotive activity in isolated fish was shown by experiments with medaka (Kanda and Itazawa, 1986), and this fact is consistent with observations in goldfish (Schuett, 1934; Escober et al., 1936; Shlaifer, 1938). Fish with an instinct to school are considered to be at ease when they are in a group and uneasy when they are isolated.

One direct cause of the group effect in the present cases was an increase in the oxygen consumption of isolated fish rather than a decrease in oxygen consumption of grouped fish. In both carp and medaka, oxygen consumption of 
isolated fish increased sharply at the postlarval stage and continued to be at relatively high levels in the juvenile stage. However, the oxygen consumption of grouped fish gradually decreased and remained at relatively low levels (Fig. 7).

Negative group effect or an increase in oxygen consumption of grouped fish has been observed in pumpkinseed Lepomis gibbosus by Brett and Sutherland (1965), blenny Blennius pholis by Wirtz and Davenport (1976), a freshwater goby Tridentiger obscurus by Umezawa et al. (1981) (In the latter two species, oxygen

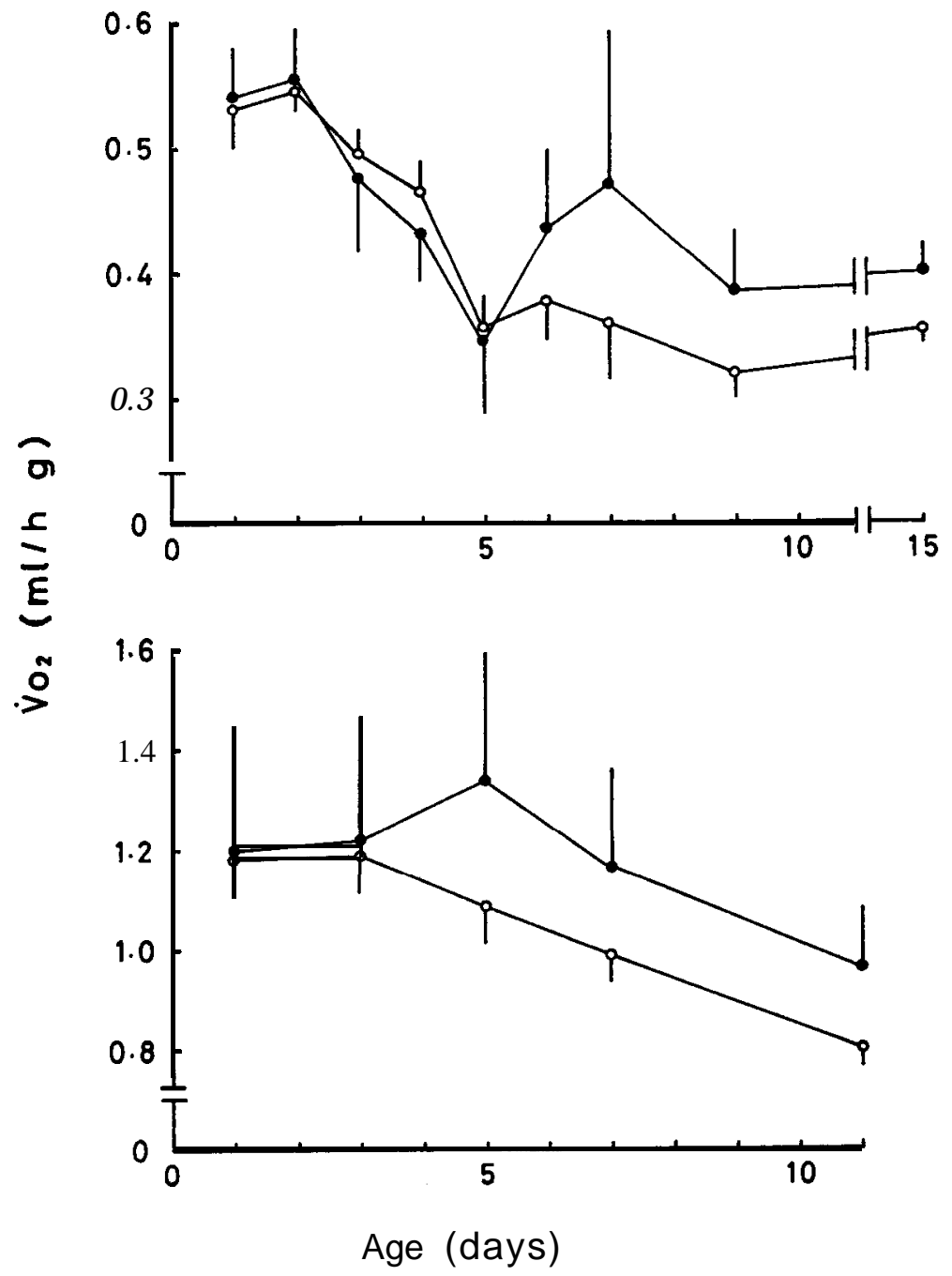

Fig. 7. oxygen consumption of carp (upper) and medaka (lower) in isolation (solid circles) and in groups (open circles) of 10 (carp) or 14 (medaka) fishes. The values are shown by the mean (circles) and a standard deviation (vertical bars). 
consumption was enhanced by visual contact with mirrored image or with separated fish of the same species), and another freshwater goby Rhinogobius brunneus by the present authors (unpublished). These species have aggressive behavior and do not live in schools. These species may be at ease when they are isolated and may be uneasy when they are in a group, thus causing the negative group effect.

\section{ACKNOWLEDGMENTS}

We wish to express our thanks to Professor J. M. Dean, University of South Carolina, for his critical reading the original manuscript and his kind suggestions and comments. We also wish to thank Dr. K. Yamamoto, Ono Limnological Station, Shimonoseki University of Fisheries, for providing the carp eggs.

\section{REFERENCES}

Brett, J. R. and D. B. Sutherland 1965 Respiratory metabolism of pumpkinseed (Lepomis gibbosus) in relation to swimming speed. J. Fish. Res. Bd. Canada, 22: 405-409

Delco Jr., E. A. and R. J. Beyers 1963 Reduced metabolic rates in males of two cyprinid fishes . Copeia, $1963: 176-178$

Escober, R. A., R. P. Minahan and R. J. Shaw 1936 Motility factors in mass physiology: Locomotor activity of fishes under conditions of isolation, homotypic grouping, and heterotypic grouping. Physiol. Zoöl., 9: 66-78

Geyer, F. and H. Mann 1939 Beiträge zur Atmung der Fische. III. Der Sauerstoffverbrauch im Gruppenversuch. Z. vergl. Physiol., 27: 429-433

Itazawa, Y., T. Matsumoto and T. Kanda 1978 Group effects on physiological and ecological phenomena in fish-I. Group effect on the oxygen consumption of the rainbow trout and the medaka. Bull. Japan. Soc. Sci. Fish., 44: 965-969

Job, S. V. 1955 The oxygen consumption of Salvelinus fontinalis. Univ. Toronto Stud. Biol. Ser., 61: 1-39

Kanda, T. and Y. Itazawa 1981 Group effect on oxygen consumption and growth of the catfish eel. Bull. Japan. Soc. Sci. Fish., 47: 341-345

Kanda, T. and Y. Itazawa 1986 Group effect on locomotor activity of larvae and juveniles of medaka. Sci. Bull. Fac. Agr., Kyushu Univ., $40: 235-238$

Konchin, V. V. 1971 The rate of oxygen consumption in the early ontogeny of the summer bakhtak [Salmo ischchan (Kessler)] when placed in respirators in groups and singly. J. Zchthyol., 11 : 916-926

Malyukina, G. A. and V. V. Konchin 1969 Development of group effects during ontogenetic development of the Baltic salmon and the Sevan trout. J. Zcthyol., 9: 292-297

Parker Jr., F. R. 1973 Reduced metabolic rates in fishes as a result of induced schooling. Trans. Amer. Fish. Soc., 102: 125-131

Ryzhkov, L. P. 1968 The rate of gaseous exchange in the eggs, larvae and fry of the Sevan trout kept in groups or isolated. J. Ichthyol., 8: 89-96

Ryzhkov, L. P. 1970 The role of certain receptors in the formation of the group effect in the bream [ Abramis brama (L.)]. J. Ichthyol., $10: 358-363$

Schuett, F. 1934 Studies in mass physiology: The activity of goldfishes under different conditions of aggregation. Ecology, $15:$ 258-262

Shlaifer, A. 1938 Studies in mass physiology: Effect of numbers upon the oxygen consumption and locomotor activity of Carassius auratus. Physiol. Zoöl., 11: 408-424 
Smatresk, N. J. and C. F. Herreid 1980 Group metabolism in swordtails, Xiphophorus helleri, under controlled oxygen conditions. Copeia, 1980 : 562-564

Stefan, M. 1958 Physiological analysis of the interrelation between the gas exchange and shoal behaviour of certain marine and freshwater species. Zoologicheskii Zhurnal, 37: 222-228

Umezawa, S., H. Ueda and H. Shibayama 1981 Group effect on oxygen consumption and some observations on the habit of the goby, Tridentiger obscurus. Annot. Zool. Japon., 54: $93-102$

Watanabe, T. and S. Hattori 1971 Gyorui no hatsuikudankai no keitaiteki-kubun to sorerano seitaiteki-tokucho. Sakana, $7: 54-59$

Wirtz, P. and J. Davenport 1976 Increased oxygen consumption in blennies (Blennius pholis L.) exposed to their mirror images. J. Fish Biol., 9: 67-74 